\title{
Interrelationship between marketing activities and the financial performance of Huawei
}

\author{
Monika Arsova ${ }^{1}$, Mila Mitreva $^{2}$, Riste Temajnovski ${ }^{3}$ \\ ${ }^{1}$ Goce Delcev University, Faculty of Economics, e-mail: monika.arsova@ugd.edu.mk \\ ${ }^{2}$ Goce Delcev University, Faculty of Economics, e-mail: mila.mitreva@ugd.edu.mk \\ ${ }^{3}$ Goce Delcev University, Faculty of Economics, e-mail: riste.temjanovski@ugd.edu.mk
}

\begin{abstract}
Today, modern businesses can not achieve their market presence without having a well-built marketing strategy. The constant revision, supplementation and modification of the strategy are part of the work of the international company. When it comes to information technology, ie the rapid growth and development of this industry requires companies that are part of it to constantly compete with the powerful and widespread competition.

Companies like Huawei are in a constant race against time, competition from all over the world and of course most importantly the desires of consumers. In order to achieve good financial results, it is necessary to constantly develop your strategy and invest in marketing tools. Through marketing, the company will be able to reach the consumer, attract him and of course keep him. In that way the profit will increase and the financial results will be in a good direction
\end{abstract}

Key words: competition; consumers; financial results; profit; strategy

\section{Introduction}

As the role of marketing becomes increasingly important in business performance, its expenses have increased over time. It is important for the company to know whether the efforts it makes in marketing activities have a good effect, ie whether better results are achieved precisely because of the investments in marketing. In practice this is very difficult given that marketing is quite a broad discipline that goes beyond the boundaries of the company itself, ie the use of distribution channels. Also, when marketing activities adjust between company purpose and customer demand, many unexpected exogenous variables affect marketing activities. [1]

For creating value for customers, clients, partners, and society, marketing must ensure positive financial outcomes that will contribute to earnings and future investment opportunities. The purpose of marketing is creating value not only for the company's customers but also for its shareholders. [2] 
In the following we will talk about the connection of marketing activities with the financial performance that the company Huawei achieves. It is a Chinese multinational technology company which designs, develops and sells telecommunications equipment, consumer electronics and various smart devices.

Huawei is ranked second-largest R\&D investor in the world and ranked fifth in the world in US patents. Huawei has deployed its products and services in more than 170 countries and areas. The company operates in all markets in the world, but invests its efforts mostly in the major markets of China and the United States. Given that the company operates internationally, ie has marketing efforts in different markets, it makes the situation much more difficult to measure its achievements in terms of investments in marketing activities.

\section{Marketing activities}

Marketing is basically realized through three activities, and each of them has a number of other sub-activities that influence the consumer. That is, the task of each of these activities is to create awareness among the consumer about the existence of the brand, attract the consumer and of course achieve higher profits for the company.

\subsection{Advertisment (AD)}

Advertisement is non-human communication delivered through mass media in order to promote commodities or services as well as to accept the idea. Traditionally, AD is the widest realized marketing communication method caused by high visibility. This high visibility is achieved by a huge expense. AD expedites demand, support to success of brand and has influence on customer behavior. Also, it offers information regarding the features of product, buying place and time to customer. AD raises brand awareness about a product through AD first and then begins to sell in order to improve efficiency. [3]

Today we cannot speak about advertising and think about television, modern way of advertising is reffereing to use of social media. Social media advertising, or social media targeting, are advertisements served to users on social media platforms. As of $2021,75 \%$ of Gen $Z$ and $48 \%$ of millennials are making purchasing decisions influenced by social media ads, and in 2020, social media ad spend in the US was valued at $\$ 40.3$ billion. [4]

\subsection{Public relations (PR)}

$\mathrm{PR}$ is a great tool to strengthen your corporate profile and to show that your company is a great place to work. Today's average consumer tends to have more of a moral compass when it comes to the companies they want to be associated with, and so your PR campaign needs to reflect this. There is increasingly more focus on a need for products to be in line with these moral expectations and for a company to have these at the forefront of their ideologies. [5] To build good business reputation company can use some of the publis relation tolls: [6]

$>\quad$ Media relations - developing good media contact lists and building relationships with key journalists

$>\quad$ Advertorials - advertisements in the form of news stories or reviews in newspapers.

$>\quad$ Social media - lets you bypass the media and go straight to your customers. Using social networking sites such as Facebook and Twitter allows you to follow and be followed by journalists 
$>\quad$ Brochures and catalogues - Properly designed brochures and catalogues give customers confidence in you and your brand, and help drive customers to your website or store.

$>\quad$ Business events - events are a chance to counter customer doubts and build customer confidence. In recent years, this is much more difficult given the pandemic caused by Covid 19. To this end, companies today organize events online to promote and communicate with consumers.

PR has concrete functions; securing an amicable press relationship, product promotion, notification about corporation, promoting legislation and regulation, conducting lobbying activities for withdrawal, coping with the market tendency and so on.

\subsection{Sales promotion (SP)}

Sales promotion is used for encouraging purchase and interest toward products. There are coupons, samples, point of purchase, lotteries, contests, rebates and exhibitions as methods of sales promotion. [7] Sales promotions are among the most effective methods of increasing sales, boosting customer satisfaction, and heightening brand awareness. Nowadays when the world is a global village and all markets are connected one of the best sales promotions tool is free shipping and free product returns. As the number of consumers shopping online grows every day, this activity can greatly attract. [8] According to WalkerSands - $80 \%$ of consumers would be more tempted to buy from Amazon if they were offered free shipping. 66\% would buy if they were offered next-day delivery and 64\% said they would buy if they were offered free returns. Free shipping and returns gives the customer a sense of security that they wont lose out if they wanted to send the product back. [9]

Each of these activities requires the company to engage labor, resources and attention in order to achieve results. That's why it's important to measure marketing investments and compare them to the financial results the company is achieving.

\section{Marketing metrics}

There are many elements and variables influencing and measuring marketing efforts' and expenses' pay-offs. Generally, marketing can produce three categories of results:

- Awareness - the rate of notarization of our brands, products and the company itself among customers. They can have different knowledge on the company which together compound their awareness on the existence of the company and its offer.

- Perception - the position the company and its offers occupy in the customers' mind. It is very important to know customer reaction toward the company and its offer and their estimation on those. It can be estimation expressed in different ways, to which the most important ones are the customer relation estimation and the competitive position compared to other companies in the market.

- Behaviour - The reaction the customers have on the company and its offer due to their awareness, perception, as well as the market conditions in the moment they are induced to react on.

And these three categories are translated in concrete terms like increase in sales volume; reduce of the payback for the investments done; speeding up the return time increasing the internal rate of return. These are some of the main indicators used to measure the marketing pay-offs. Marketing metrics could be defined as measurements that help with the quantification of marketing performance through figures, indexes or else in order to prove and display the pay-offs of marketing in an enterprise. They provide evidence on customer experience, on 
service delivery, on customer loyalty, on increments on sales, image, customer perception on the company, audience coverage, profit and return on investments. [10] Most of the companies do not measure the performance of marketing in financial terms. They use integral indicators to calculate for the results of marketing in a generic way. They need to measure efficiency of the investment done on marketing - Promotion, distribution, sales, customer relations etc. As the marketing officers are too much given to entrepreneurial skills, as well as very operative in their decision making, focussing more on performance rather than in financial results, or pay-offs in financial terms, it would be very useful and important to measure the effect of their actions and the profitability of the investments done in marketing. [11]

\section{The Impact of Marketing Activities on Business Performance Indicators}

Marketing expenditures are funds of companies that are allocated to spending on advertising and other marketing communication activities such as digital and mobile marketing, press conferences, experiential marketing events and sales promotions. Marketing expenditures are not only shortterm expenditures but also long-term investments for a company since marketing activities contribute to the firm's brand equity that will improve the profit margin, current and future earnings. [12] Marketing expenditures may exceed capital expenditures and although companies do not disclose marketing expenditures as consistently as financial expenditures, marketing expenditures are effective on future sales and market value of a company. [13]

Studies regarding the relationship between marketing investments and business performance are mainly emphasizing the positive impact of marketing investments and market measures of firms. Graham \& Frankenberger found out that advertising and promotion expenditures are marketing communication investments that contribute to current and future earnings. [14] Also, Joshi and Hanssens have shown that advertising expenditures positively influence the market value of firms and the responses of investors beyond the expected increase in sales and profits. [15] Brand value is one of the main marketing parameters that is associated with a firm's financial performance. The impact of marketing activities, marketing investments on the company's performance is constantly monitored and when necessary, corrective measures are taken.

Marketing greatly affects the revenue that the company generates. What makes it difficult to measure on the one hand is the long-term effect, ie the marketing that is applied today can have an impact much later. It is also very difficult to measure the results achieved by each individual marketing activity.

One of the ways to generate revenue for a company is to use online advertising. Online ads are typically purchased on a cost-per-thousand (CPM), cost-per-click (CPC) or cost-peracquisition (CPA) basis: [16]

- Cost per thousand (CPM). You pay a fixed fee per thousand advertising impressions. (The $\mathrm{M}$ in CPM is the Roman numeral for 1,000.)

- Cost per click (CPC). You pay a fixed fee every time a user clicks on your ad and is redirected to your website.

- Cost per acquisition (CPA). You pay a fixed fee every time someone clicks on your ad and completes a desired action on your website, such as submitting an order or signing up for your newsletter.

In addition to creating these revenues, of course, online advertising will affect in another way, ie it will attract consumers and keep some of them as consumers, and thus will increase sales revenues. It is very important to see the markets in which the company operates, whether nationally or internationally, the industry in which it operates and of course the type of market structure is very important. 
In addition, one of the leaders in information technology, the Chinese company Huawei, which operates internationally and serves a large number of consumers in the world, will be processed.

\section{Huawei's marketing activities and their impact on financial performance}

Huawei is a privately held company, based in Shenzhen, China. Being founded in 1987, the company has come a long way and within a span of 30 years, Huawei is today a global behemoth competing against the giants like Apple, Samsung and Google. The company is internationally present and competes with major giants in information technology. By 2020, Huawei has over 194,000 employees and has bases in over 170 countries and regions around the world, serving more than three billion people. Its business is highly diversified into various segments related to communications, designed to cater for the needs of different individuals, enterprises and government agencies. Huawei is not a shareholder-owned company but instead is controlled by its employees. Huawei Technologies Co., Ltd. is a subsidiary of Huawei Investment \& Holding which has two shareholders, Huawei's labor union and the company's founder Ren Zhengfei.

The three primary business segments of Huawei include:

- Carrier business

- Consumer business

- Enterprise business

Huawei uses both the channels, the digital method and the traditional method for marketing purposes. As in digital marketing, the core objective of Huawei is to use different social networks and websites which include Facebook, Twitter, Google etc. to promote their various products. [17]

Some of the marketing strategies that HUAWEI has implemented over the years have been a real cost to them. Many of their profits are set aside to increase brand awareness and of course attract more customers.

\section{* Brand Ambassador Strategy of Huawei}

Huawei works with celebrities to promote its products. It has collaborated with various popular celebrities like football stars Lionel Messi, Antoine Griezmann, Hollywood Actress Gal Gadot and Saina Nehwal in India.

\section{- $\quad$ Product Display Strategy of Huawei}

Huawei's strategy of showcasing new products on the large-scale exhibition. During such events, the company also engaged with industry partners and experts to demonstrates the innovations and future trends in the mobile industry.

Beside this two, Huawei in its operations it has used and still uses a number of different strategies through which it attracts consumers. In fact, each of these strategies involves modern marketing, organized and realized through various social media and other marketing tools that have an impact on the modern consumer. The company also uses marketing channels to advertise anywhere in the world. The use of different strategies, using different tools and channels to reach the consumer affects its revenue. 
In addition, Figure 1 presents the revenues that the company has achieved from 2012 to 2020 in different global regions. (revenue is shown in Yuan - the currency of China)

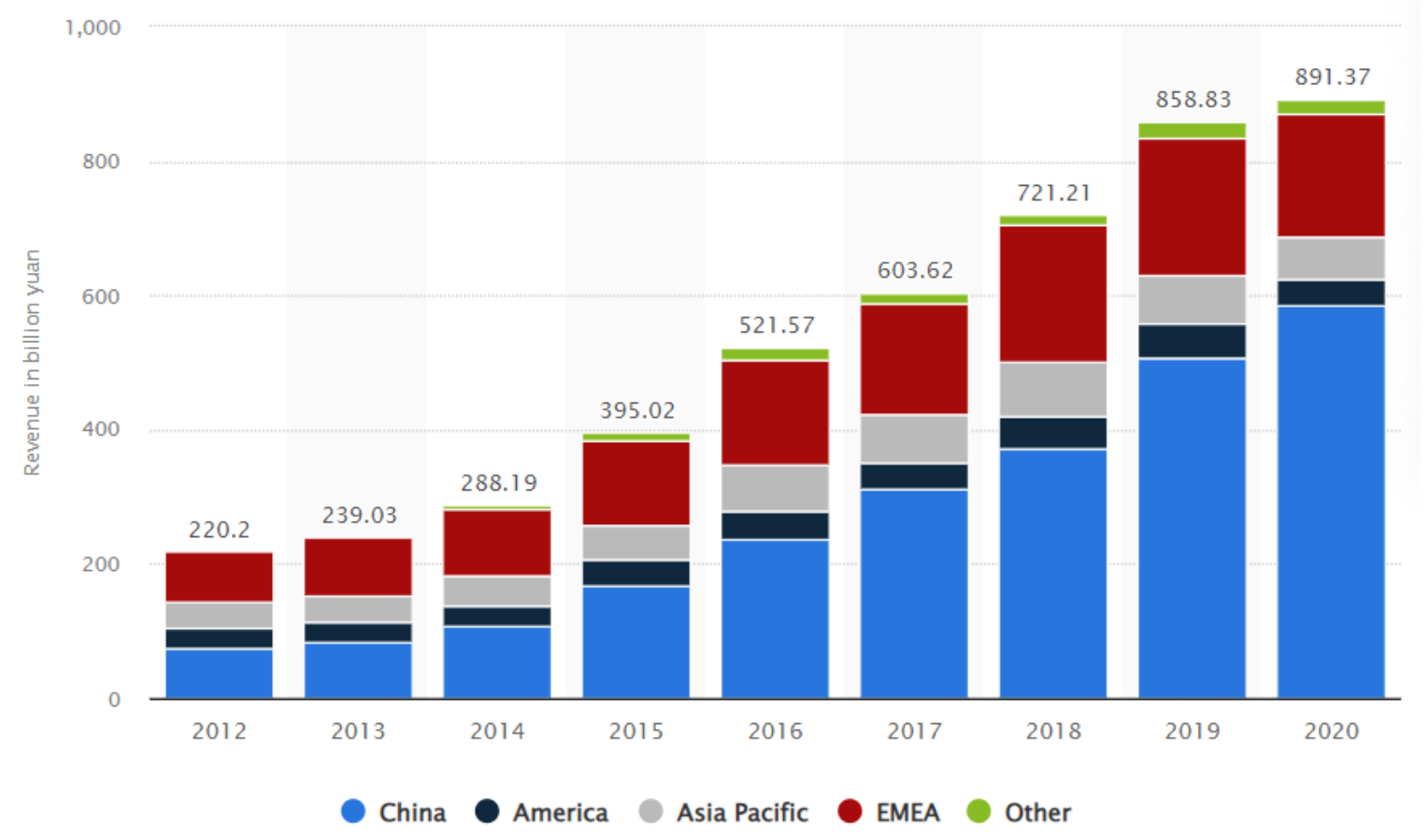

Figure 1: Huawei's revenue from 2012 to 2020, by geographical region

Source: https://www.statista.com/statistics/368509/revenue-of-huawei-by-region/

As can be seen, the company generates the highest revenue on the domestic market in China and it is growing every year. In the EMEA region (Europe, Middle East and Africa) there is an increase in revenue which means that in these markets brand awareness begins to grow due to marketing activities. What is also noticeable is that the presence of the brand or the awareness of it, and thus the attraction of consumers within other countries grows over the years.

In addition, you can see how the company's revenues moved in the period from 2016 to 2020, and also their cash flow from operating activities and operating profits at the same period.

Table 1 Revenues of the company in the period 2016 - 2020 (USD million)

\begin{tabular}{|l|c|c|c|c|c|}
\hline Year & 2020 & 2019 & 2018 & 2017 & 2016 \\
\hline Revenue & $\mathbf{1 3 6 , 7 1 7}$ & $\mathbf{1 3 5 , 0 1 1}$ & $\mathbf{1 1 3 , 3 7 5}$ & $\mathbf{9 4 , 8 9 1}$ & $\mathbf{8 1 , 9 8 7}$ \\
\hline
\end{tabular}

Resoruce: https://www-file.huawei.com/minisite/media/annual_report/annual_report_2020 en.pdf

As can be seen there is a noticeable increase every year in the company's revenues. Undoubtedly, the impact of marketing activities is given that every year the number of marketing campaigns grows and of course the presence of the company expands to more markets thanks to marketing ads on social media.

Attached are shown cash flow from operating activities and operating profits of the company for the period $(2016-2020)$. 


\section{Operating profit}

(in USD million)

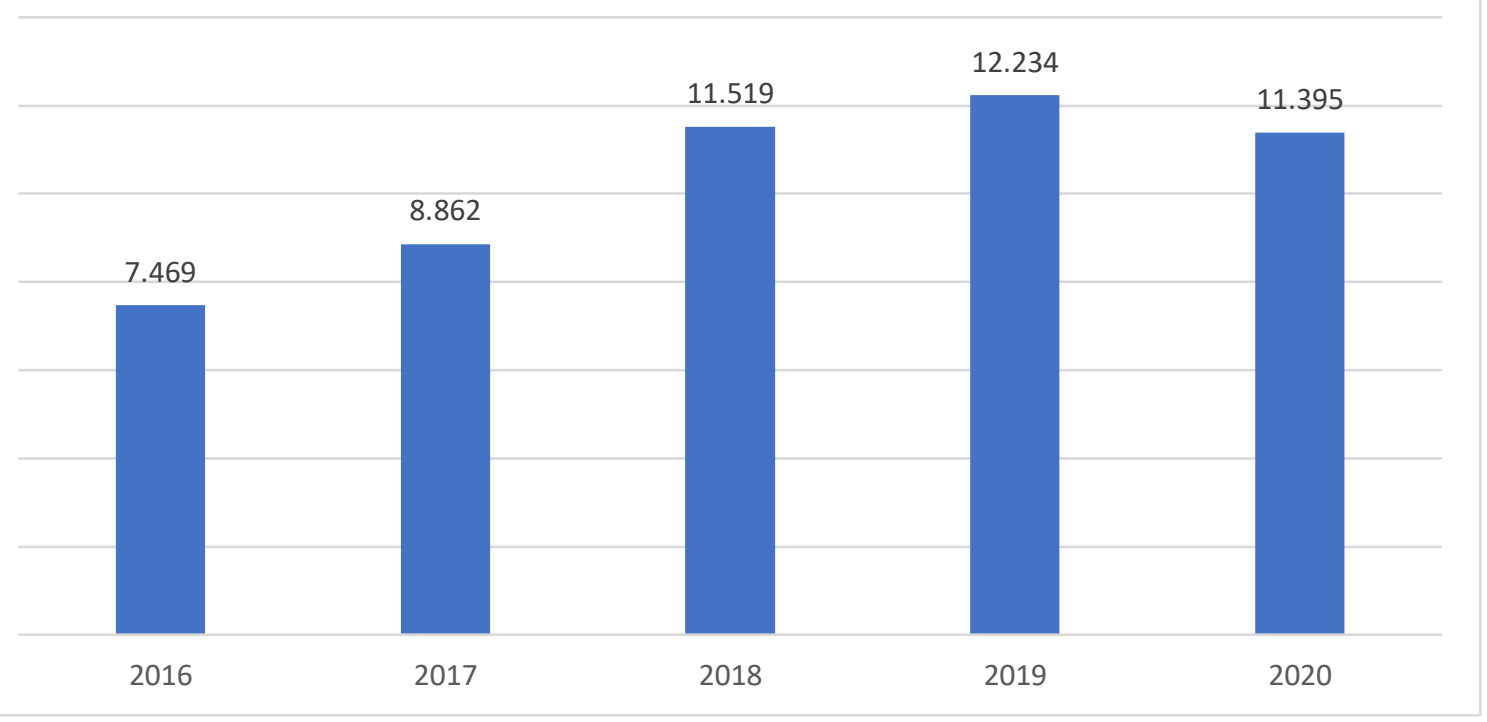

Figure 2 Operating profit of HUAWEI

Source: https://www-

file.huawei.com/minisite/media/annual report/annual report 2020 en.pdf

Their operating profit is growing from year to year, but has declined in 2020 due to the pandemic caused by Covid 19. Consumer spending was reduced at the beginning of the pandemic as there was an uncertain situation for which consumers could not know what it would bring so they did not spend their money on luxury goods.

Next figure (3) contains the Cash flow from operating activities that indicates the amount of money a company brings in from its ongoing, regular business activities, such as manufacturing and selling goods or providing a service to customers. Operating activities include generating revenue, paying expenses and funding working capital. It is calculated by taking a company`s net income, plus adjusting for non-cash items and also accounting for changes in working capital. [18]

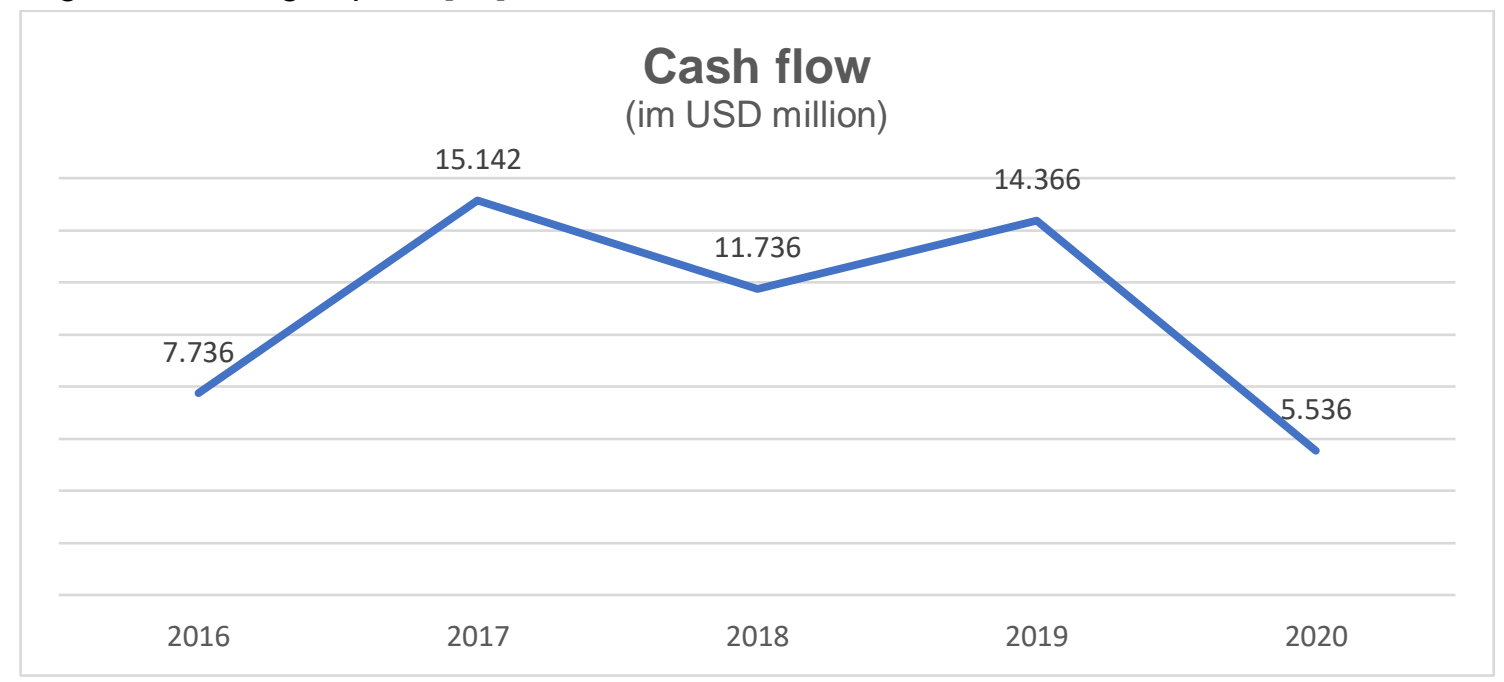

Figure 3 Cash flow from operating activities $(2016$ - 2020)

Source: https://www-file.huawei.com/minisite/media/annual report/annual report 2020 en.pdf https://www.huawei.com/-/media/corporate/pdf/annual-report/annual report2017 en.pdf?la=en 
Cash flow from operating activities in 2017 grew by $95.7 \%$. This was caused by two factors:

- Net profit grew by $28.1 \%$ year-on-year.

- In 2017, changes in operating assets and liabilities contributed CNY33,911 million to the cash flow from operating activities. This was mainly attributable to the rapid growth of the consumer business and efficiency gains in the carrier and enterprise businesses made possible by ongoing management improvements.

The reason for the decrease in cash flow in 2020 is due to increased investment in areas like cloud and R\&D, an increase in depreciation and amortization, and a decline in accounts payable.

The financial results shown are due to the long, persistent and persistent work of the Huawei team. The constant effort, resources and intellect that the company invests in its work give these results. The production, research, growth and development of various innovative models as well as marketing efforts made it possible to obtain the displayed financial results

\section{Conclusion}

Undoubtedly and inevitably, the impact of marketing on the achievement of financial results in modern businesses. HUAWEl is one of the leaders in its industry, both in terms of innovation and the way it works. Judging by their financial results, they show that they show growth in every year, even in the last year when Covid 19 has a huge impact on the work of each entity. Over the years, the company has invested in marketing campaigns that have had a positive impact in terms of attracting new customers and certainly boosting consumption among existing customers by launching new products. To promote their product innovations, campaigns are often used that cost a lot, ie the fame of many famous people in the world is used. It has a positive impact and of course the given financial parameters indicate the opportunities that the company has for the coming years. Achieving good returns provides an opportunity to reinvest in the coming years and further develop the company's capacity.

\section{References:}

[1] Rust Roland, Tim Ambler, Gregory Carpenter, Kumar and Rajendra Srivastava (2004), "Measuring Marketing Productivity: Current Knowledge and Future Directions," Journal of Marketing, 68 (4), 76-89

[2] Madden, T.J., Fehle, F., \& Fournier, S. (2006), "Brands Matter: An Empirical Demonstration of The Creation of Shareholder Value Through Branding", Journal of the Academy of Marketing Science, 34(2), 224-235.

[3] Baek H.Y. (2014) Effect of Marketing Activities on Financial Performance: An Empirical Analysis. Journal of Marketing Thought 01(02), p. 69-79

[4] Reed H. (2021) How to Choose the Right Platform and Ads for Your Brand. Branding Strategies. bigcommerce.com (Accessed on: 27.01.2022 https://www.bigcommerce.com/blog/social-media-advertising/)

[5] Mayhew C. (2012) Using Publis Relations as a marketing tool. Paraduxmedia.com (Accessed on: 27.01.2022 https://paraduxmedia.com/public-relations-marketing-tool/)

[6] Pedersen C. (2016) How to use PR as a marketing tool. Managemagazin.com (Accessed on: 28.01.2022 https://managemagazine.com/article-bank/public-relations/how-to-use-pr-as-a-marketing-tool/)

[7] Matsuno K. and Mentzer J. (2000), "The Effects of Strategy Type on the Market OrientationPerformance Relationship," Journal of Marketing, 64 (4) 1-16 
[8] Gyant N. (2021) 15 Insanely effective sales promotion examples to win more customers. WordStream.com (Accessed on: 28.01.2022 https://www.wordstream.com/blog/ws/2020/10/13/salespromotion-examples)

[9] Team AmeriCommerce (2020) The 10 top most popular types of sales promotions (Accessed on: 27.01.2022 https://www. americommerce.com/the-top-10-most-popular-types-of-sales-promotions)

[10] Uncles, M. (2005). "Marketing Metrics: A can of worms or the path to enlightenment." Brand Management. p.412-418

[11] Fetahu E. (2014) DOES MARKETING RELATE TO FINANCE? - "MARKETING IS FINANCE?" THEORETICAL PERCEPTION. European Journal of Business and Economics 9 (2).

[12] Graham, R.C.J.R. \& Frankenberger, K.D. (2000), "The Contribution of Changes in Advertising Expenditures to Earnings and Market Values", Journal of Business Research, 50, 149-155.

[13] Sydney-Hilton, E. \& Vila-Lopez, N. (2019), "Are Marketing Strategies Correlated with Financial Outputs? A Longitudinal Study", Journal of Business \& Industrial Marketing, 34(7), 1533-1546.

[14] Graham, R.C. \& Frankenberger, K.D. (2011), "The Earnings Effects of Marketing Communication Expenditures During Recessions", Journal of Advertising, 40 (2), 5-24.

[15] Joshi A. \& Hanssens D. M. (2010), "The Direct and Indirect Effects of Advertising Spending on Firm Value", Journal of Marketing, 74(1), 20-33.

[16] Enright M. (2020) Online advertising can boost revenue. Wolters Kluwer (Accessed on: 28.01.2022 https://www.wolterskluwer.com/en/expert-insights/online-advertising-can-boost-revenue)

[17] Shastri A. (2021) Deep Dive into Huawei's Millennial marketing strategy: A case study. The digital school (Accessed on: 27.01.2022 https://iide.co/case-studies/marketing-strategy-huawei/)

[18] Murphy C. B. (2022) Understanding the Cash Flow Statement. Investopedia (Accessed on: 28.01.2022 https://www.investopedia.com/investing/what-is-a-cash-flow-statement/) 